\title{
MEMBANGUN PERADABAN DENGAN KONSEP MUTTAQIN DAN IMAMA
}

\author{
M Fahim Tharaba \\ Email : fahimtarbiyah@yahoo.com \\ Universitas Islam Negeri Maulana Malik Ibrahim Malang
}

\begin{abstract}
Civilization is built not only in the form of idofact, it needs to be felt in the real form in sociofact, even manifested in artifact. In bringing about an independent civilization, Islam has a very remarkable concept in the form of the concept of muttaqin and imama. This article discusses the competencies exemplified by Rasulullah saw in building civilization through education and the concept of muttaqin and imam in building a generation with civilization
\end{abstract}

Keywords: Building Civilization, Muttaqin and Imama

\begin{abstract}
Abstrak
Peradaban dibangun tidak hanya dalam bentuk idofact, perlu dirasakan dalam wujud nyata dalam sosiofact, bahkan diwujudkan dalam artifact. Dalam mewujudkan peradaban yang mandiri, Islam telah punya konsep yang sangat luar biasa dalam bentuk konsep muttaqin dan imama. Artikel ini membahas kompetensi-kompetensi yang dicontohkan rasulullah saw dalam membangun peradaban lewat pendidikan serta konsep muttaqin dan imam dalam membangun generasi dengan peradaban
\end{abstract}

Kata kunci: Membangun Peradaban, Muttaqin dan Imama

\section{Pendahuluan}

Peradaban harus diwujudkan sebagai bukti kemajuan suatu masyarakat, bahkan bangsa yang tak terbantahkan. Dalam sejarahnya muncul peradaban zaman batu, seperti peradaban zaman Megalitikum, zaman Mesolitikum, bahkan zaman Neolitikum, perdaban juga muncul di zaman logam, bahkan terus berkembang memunculkan berbagai perdaban di dunia, seperti peradaban zaman Yunani, peradaban zaman Romawi, dan seterusnya, sampai memunculkan peradaban Islam yang luar biasa, sebagai puncaknya peradaban di zaman Abasyiah. Perdaban ini, akan selalu muncul mengiringi perkembangan manusia, bahkan sampai era Sibernetik saat ini, dengan munculnya teknologi sebagai wujud peradaban manusia.

Peradaban dibangun tidak hanya dalam bentuk idofact, perlu dirasakan dalam wujud nyata dalam sosiofact, bahkan diwujudkan dalam artifact. Dalam mewujudkan peradaban yang mandiri, $\mathrm{Al}$
Qur'an Surat Ar Ra'du ayat 11 menyebutkan:

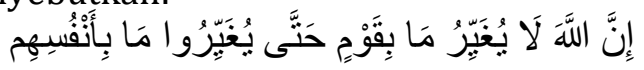

Artinya: "Allah tidak akan merubah nasib suatu kaum hingga kaum itu mau berusaha untuk merubah dirinya sendiri".

Dari ayat ini jelas bahwa dalam Islam perubahan haruslah sesuatu yang dimanaj dan diupayakan secara cermat sehingga akan membawa perbaikan dalam kehidupan manusia untuk mewujudkan peradaban. Untuk merancang dan membuat perubahan memang bukan satu hal yang sederhana. Namun memerlukan upaya dan kerja keras sehingga dapat membuahkan hasil. Pada ayat lain dijelaskan tentang pentingnya perubahan paradigma dalam melihat realitas dalam kerangka membangun masa depan.

Selanjutnya, dalam Al Qur'an surat Al Hasyr ayat 18 disebutkan:

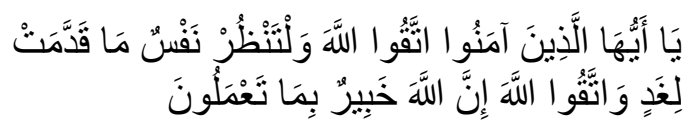


Ayat ini menegaskan tentang pentingnya paradigm baru dalam menata kehidupan masa depan. Masa depan dengan segala dinamika perubahannya harus dapat diantisipasi oleh generasi sekarang melalui penyiapan kemampuan membaca dan berfikir futuristic. Apapun perubahan yang terjadi dan yang akan terjadi harus diikuti dengan kemampuan cara pandang yang holistic dan tepat sehingga mampu melahirkan soluasi alternatif yang sesuai dengan visi dan keyakinan bahwa Islam selalu mampu menjawab persoalanpersoalan keumatan kapanpun dan di manapun.

Oleh karenanya, pendidikan sebagai salah satu pilar utama untuk mengantisipasi masa depan, karena pendidikan selalu diorientasikan pada penyiapan peserta didik (mahasiswa) untuk berperan di masa yang akan datang, dalam rangka mewujudkan peradaban yang luar biasa. Sehingga dalam membangun generasi dengan peradaban yang luar biasa sebagai pengimplementasian bahwa Islam sebagai sebuah ajaran yang diyakini memiliki karakteristik "sholihun likulli zamaan wa makan" diperlukan tiga (3) hal, yaitu:

a. العدوة (kemauan).

b. الإسنطاعة (kemampuan).

c. الأسوة (contoh teladan). (Fahim, 2016: 150/ Fahim, 2008, Kuliah Kapita)

Dalam membangun generasi dengan peradaban yang luar biasa, salah satunya ditegaskan dalam al-Qur'an Surat al-Furqon ayat 74, terutama dengan konsep Muttaqin dan Imam. Banyak yang berpendapat tentang dengan konsep Muttaqin dan Imam, dalam paparan ini, penulis mencoba menggali dan mengulasnya secara lebih dalam dan khusus.

\section{Pembahasan}

\section{Kompetensi-Kompetensi yang Dicontohkan Rasulullah SAW dalam Membangun Peradaban Lewat Pendidikan}

Peradaban dibangun dengan profesionalitas yang tinggi, kita dapat mengacu pada tuntunan Nabi SAW., karena beliau satu-satunya pendidik yang paling berhasil dalam rentang waktu yang begitu singkat, sehingga diharapkan dapat mendekatkan realitas (pendidik) dengan yang ideal (Nabi SAW.). Keberhasilan Nabi SAW. sebagai pendidik didahului oleh bekal kepribadian (personality) yang berkualitas unggul, kepeduliannya terhadap masalah-masalah sosial relegius, serta semangat dan ketajamannya dalam iqra' bi ismi rabbika (membaca, menganalisis, meneliti, dan mengeksprementasikan berbagai fenomena kehidupan dengan menyebut nama Tuhan), kemudian beliau mampu mempertahankan dan mengembangkan kualitas iman, amal seholeh, berjuang, dan bekerja sama menegakkan kebenaran (QS. al-Ashr, al-Kahfi: 20), mampu bekerja sama dalam kesabaran (QS. al-Ashr: 3, QS. alAhqaf: 35, dan QS. Ali-Imran: 200).

Dari hasil telaah tersebut, dapat diformulasikan asumsi yang melandasi keberhasilan pendidik dalam membangun peradaban, yakni: "Pendidik akan berhasil menjalankan tugasnya, apabila mempunyai kompetensi personal-relegius, socialrelegius, dan profesional-relegius".

Kata relegius selalu dikaitkan dengan tiap-tiap kompetensi, karena menunjukan adanya komitmen pendidik dengan ajaran Islam sebagai kriteria utama, sehingga segala masalah pendidikan dihadapi, dipertimbangkan, dan dipecahkan, serta ditempatkan dalam perspektif Islam.

a. Kompetensi Personal-Religius

Kemampuan dasar (kompetensi) yang pertama bagi pendidik adalah menyangkut kepribadian agamis, artinya pada dirinya melekat nilai-nilai lebih yang hendak ditransinternalisasikan kepada peserta didiknya, misalnya nilai kejujuran, amanah, keadailan, kecerdasan, tanggungjawab, musyawarah, kebersihan, keindahan, kedisiplinan, ketertiban, dan sebagainya. Nilai tersebut perlu dimiliki pendidik sehingga akan terjadi transinternalisasi (pemindahan penghayatan nilai-nilai) antara 
pendidik dan peserta didik, baik langsung maupun tidak langsung, atau setidak-tidaknya terjadi transaksi (alih tindakan) antara keduanya.

b. Kompetensi Sosial-Relegius

Kemampuan dasar kedua bagi pendidik adalah menyangkut kepeduliannya terhadap masalahmasalah sosial selaras dengan ajaran dak'wah Islam. Sikap gotong-royoong, tolong-menolong, egalitarian (persamaan derajat antara manusia), sikap toleransi, dalam rangka transinternalisasi sosial atau transaksi sosial antara pendidik dan pesertapeserta didik.

c. Kompetensi Profesional-Relegius

Kemampuan dasar ketiga ini menyangkut kemampuan untuk menjalankan tugas keguruannya secara profesional, dalam arti mampu membuat keputusan keahlian atas beragamnya kasus, serta mampu mempertanggungjawabkan berdasarkan teori dan wawasan keahliaannya dalam perspektif Islam.

Dalam versi yang berbeda, kompetensi pendidik dapat dijabarkan dalam beberapa kompetensi sebagai berikut: (1) mengetahui hal-hal yang perlu diajarkan, sehingga ia harus belajar dan mencari informasi tentang materi yang diajarkan; (2) menguasai keseluruhan bahan materi yang akan disampaikan pada peserta didiknya; (3) mempunyai kemampuan menganalisis materi yang diajarkan dan menghubungkannya dengan konteks komponen-komponen lain secara keseluruhan melalui pola yang diberikan Islam, tentang bagaimana cara berfikir (way of thinking) dan cara hidup (way of life) yang perlu dikembangkan melalui proses edukasi; (4) mengamalkan terlebih dahulu informasi yang telah didapat sebelum disajikan pada peserta didiknya (QS. as-Shaf: 2-3; (5) mengevaluasi proses dan hasil pendidikan yang sedang dan sudah dilaksanakan (QS. al-Baqarah: 31); (6) memberi hadiah (tabsyir/reward) dan hukuman (tandzir/punisment) sesuai dengan usaha dan upaya yang dicapai peserta didik dalam rangka memberikan persuasi dan motivasi dalam proses belajar (QS. al-Baqarah: 119).

Kompetensi pendidik yang tidak kalah pentingnya adalah memberikan uswah hasanah dan meningkatkan kualitas dan profesionalitasnya yang mengacu kepada masa depan tanpa melupakan peningkatan kesejahteraaan, misalnya gaji, pangkat, kesehatan, perumahan, sehingga pendidik benar-benar berkemampuan tinggi dalam tranfer of heart, transfer of head, dan transfer of hand kepada peserta didik dan lingkungannya, serta mencegah adanya pepatah "Guru kencing berdiri, murid kencing berlari" yang pada gilirannya akan lebih ironis lagi dengan pepatah: "Guru kencing berdiri dan murid mengencingi guru". (Abdul Mujib, 2006: 9397)

Selanjutnya, dalam membangun peradaban harus mengimplementasikan bahwa Islam sebagai sebuah ajaran yang diyakini memiliki karakteristik "sholihun likulli zamaan wa makan". Artinya Islam akan mampu hidup dan compatible dengan situasi dan kondisi kapanpun (tempus) dan di manapun (lokus).

Islam adalah agama yang memiliki visi perubahan. Syariat Islam yang diturunkan oleh Allah kepada umat manusia melalui rasul-rasulnya berisi tentang ajaran-ajaran yang berorientasi pada terjadinya perubahan kehidupan. Rasulullah yang merupakan pengemban utama risalah kenabian itu menyatakan bahwa misi beliau adalah liutammima makarimal akhlaq. Tugas ini menyiratkan tugas sebagai agen perubahan, merubah masyarakat jahiliyah menjadi masyarakat beradab.

M. Hajar Dewantoro, dalam "Urgensi Inovasi Pendidikan Dalam Pemberdayaan Umat", mengungkapkan terdapat beberapa faktor yang mempengaruhi keberhasilan implementasi gagasan perubahan atau inovasi dalam penyelenggaraan pendidikan, yaitu:

a. Karakteristik dari konteks di mana perubahan atau inovasi itu terjadi dan konteks tersebut merupakan 
faktor-faktor budaya, ekonomi, politik dan sebagainya.

b. Karakteristik dari strategi pelaksanaan perubahan atau inovasi, dalam hal ini apakah sumber-sumber yang diperlukan untuk implementasi tersebut cukup tersedia.

c. Karakteristik para pelaku dari proses inovasi (perencana, pelaksana, guru dan sebagainya) dan sejauhmana terdapat komitmen untuk melaksanakan perubahan inovasi tersebut.

d. Karakteristik dari perubahan atau inovasi itu sendiri, yaitu kompleksitas program inovasi, biaya yang diperlukan, fasilitas, sejauh mana inovasi tersebut tidak menggoyahkan sistem yang telah ada dan mapan, birokrasi, dan kepentingan-kepentingan ekonomi serta politik.

e. Karakteristik dari proses perubahan atau inovasi itu sendiri, misalnya, waktu pelaksanaannya, konsep perubahan yang menjadi dasar dari inovasi tersebut.

Menurut King dan Anderson (1995), sebagaimana dikutip Winardi (2005), pembaharuan dalam manajemen keorganisasian memerlukan tiga hal:

a. Orang kreatif (the creative person).

b. Proses kreatif (the creative process).

c. Produk kreatif (the creative product).

Sehingga dalam membangun peradaban sebagai pengimplementasian bahwa Islam sebagai sebuah ajaran yang diyakini memiliki karakteristik "sholihun likulli zamaan wa makan" diperlu tiga (3) hal, yaitu:

a. العدوة (kemauan).

b. الإسنطاعة (kemampuan).

c. الأسوة (contoh teladan). (Fahim, 2016: 150/ Fahim, 2008, Kuliah Kapita)

Oleh karenanya, dalam membangun peradaban yang Islami yang diyakini memiliki karakteristik "sholihun likulli zamaan wa makan" harus dilengkapi dengan Total Quality Management (TQM), yaitu:

a. Customer Focus.

b. Total Involvement.

c. Continous Improvement.

Oleh karenanya terdapat satu prinsip yang cukup bijaksana terkait dengan implementasi gagasan perubahan dalam pengelolaan lembaga pendidikan Islam membangun peradaban, yakni"

$$
\text { المحافظة على القديم الصالح و الأخذ بالجديد الأصلاح }
$$

"Melestariakan yang terdahulu yang shaleh, dan mengambil yang belakangan yang lebih baik".

Selain itu, dalam implementasi gagasan perubahan dalam pengelolaan lembaga pendidikan Islam membangun peradaban tidak lepas dari isi kurikulum pendidikan Islam dengan tiga orientasi, yang berpijak pada al-Qur'an Surat Fushilat ayat 53:

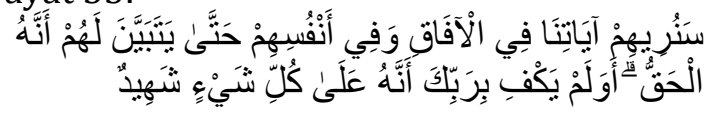

Terjemahnya: "Kami akan memperhatikan kepada mereka tanda-tanda (kekuasaan) kami di segenap ufuk dan pada diri mereka sendiri (anfus). Sehingga jelaslah bagi mereka bahwa al-Qur'an itu benar. Dan apakah Tuhanmu tidak cukup (bagimu) bahwa sesungguhnya Dia menyaksikan segala seseuatu". (QS. Fushilat: 53)

Dalam ayat tersebut terkandung tiga isi orientasi pengembangan pendidikan Islam dalam rangka membangun peradaban, yaitu:

a. Isi pengembangan pendidikan Islam yang berorientasi pada "Ketuhanan". Rumusan isi pengembangan pendidikan Islam yang berkaitan dengan Ketuhanan, mengenai Dzat, Sifat, perbuatanNya, dan relasinya terhadap manusia dan alam semesta. Bagian ini, meliputi ilmu kalam, ilmu metafisika alam, ilmu fiqh, ilmu akhlak, (tasawuf), ilmu-ilmu tentang al-Qur'an dan as-Sunah (tafsir, musthalah, linguistik, ushul fiqh, dan sebagainya). Isi pengembangan pendidikan Islam ini berpijak pada wahyu Allah SWT. 
b. Isi pengembangan pendidikan Islam yang beroreintasi pada "kemanusiaan" rumusan isi kurikulum yang berkaitan dengan perilaku manusia, baik manusia sebagai makhluk individu, mahluk sosial, mahluk berbudaya, dan mahluk yang berakal. Bagian ini, meliputi ilmu politik, ekonomi, kebudayaan, sosiologi, antropologi, sejarah, linguistik, seni, arsitek, filsafat, psikologi, paedagogis, biologi, kedokteran, perdagangan, komunikasi, administrasi, matematika, dan sebagainya. Isi pengembangan pendidikan Islam ini berpijak pada ayat-ayat anfusi.

c. Isi pengembangan pendidikan Islam yang berorientasi pada "kealaman". Rumusan isi kurikulum yang berkaitan dengan fenomena alam semesta sebagai mahluk yang diamanatkan dan untuk kepentingan manusia. Bagian ini, meliputi ilmu fisika, kimia, pertanian, perhutanan, perikanan, farmasi, astronomi, ruang angkasa, geologi, geofisika, botani, zologi, biogenitik, dan sebagainya. Isi pengembangan pendidikan Islam ini berpijak pada ayat-ayat afaqi. (Fahim, 2016, Kuliah Dasar-dasar Pendidikan Islam)

Sebagaimana sering diungkap Imam Suprayogo dengan ayat-ayat qouliyah dan ayat-ayat kauniyah (penelitian, observasi, teknologi, dst.), senda dengan yang diungkapkan Muhaimin, yaitu: itba' lisyariatillah, dan itba' lisunnatillah.

\section{Konsep Muttaqin Dan Imam Dalam Membangun Generasi Dengan Peradaban}

Konsep Muttaqin dan Imam dalam prespektif al-Qur'an dalam membangun peradaban dimulai dari memilih jodoh (pendidikan). Dalam hal ini Islam menggariskan dengan hadis Rasulullah SAW.,

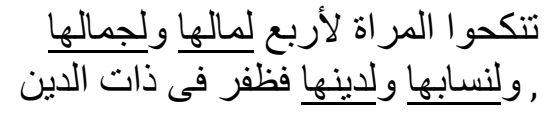

yang kalau diterjemahkan di dalam pendidikan, pendidikan yang dipilih adalah yang mempunyai kriteria (1) لمالها (fasilitas lengkap), (2) لجمالها (visi misinya menarik), (3) لنسابها (jelas rujukannya al-Qur'an dan sunnah, dst.), (4) لدينها (landasan aqidahnya sesuai), dan (5) Selanjutnya, pendidikan tersebut diarahkan dalam rangka mencetak (ذرية قرة اعين), dalam hal ini, adalah pendidikan pra, dasar dan menengah. Untuk selanjutnya diarahan dalam mencapai derajat (منقين), dan ini diraih sempurna lewat pendidikan sarjana (S-1/Sarjana), bahkan derjat (متقين) disempurnakan lagi lewat pendidikan pascasarjana strata dua (S-2/Magister) dan puncaknya adalah (امام) diraih dengan pendidikan di strata tiga (S-3/Doktor). Dan derajat tertinggi (امام) disempurnakan dengan Gelar Profesor di bidang/profesi apapun.

Konsep Muttaqin dan Imam, selanjutnya menjadi perhatian khusus. Konsep Muttaqin, kalau diibaratkan dengan angka, muttaqin itu baru angka 1. Apa ini maksudnya?, angka satu itu dalam konsep matematika, dipangkatkan berapapun, akan tetap satu. Oleh karena itu, kalau baru sampek derajat sarjana, baru sampek muttaqin, sehingga kalau menjadi imam, masih perlu tambahan strata, sehingga, ada daya tambah dari hasil perannya. Coba setalah angka satu, dua, tiga, dst. semakin banyak pangkatnya, semakin besar nilainya, jadi derajat Imama (konsep Imama) itu harus dilalui setelah sarjana untuk memberi nilai lebih besar; magister dan bahkan doktor. Akan tetapi, ini walaupun besar nilai perannya, belum bisa menghasilkan kebijakan yang sempurna (berijtihad), jadi mujtahid. Mujtahid tercapai kalau di atas semua strata, jadilah professor. Hal itu dipertegas al-Qur'an Surat al-Furqon ayat 74,

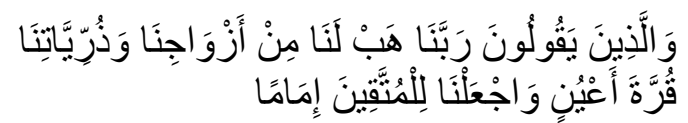

Terjemahnya:

Dan orang orang yang berkata "Ya Tuhan Kami, anugrahkanlah kepada Kami isteri- 
isteri Kami dan keturunan Kami sebagai penyenang hati (Kami), dan Jadikanlah Kami imam bagi orang-orang yang bertakwa”.(QS. al-Furqon: 74)

Oleh karena itu, konsep Muttaqin dalam prespektif al-Qur'an tepatnya Surat alFurqon ayat 74 adalah konsep utuhnya, jadi angka satu, baru sempurna satu, perlu disempunakan lagi dengan strata magister, lalu lengkap sempurna dengan doktor, untuk memberi nilai tambah dan guna peran yang lebih dan luar biasa. Sebagai puncaknya, konsep mujtahid (professor) yang melampaui strata itu, sehingga menghasilkan betul-betul kreasi baru (discovery) yang selalu up to date "sholihun likulli zamaan wa makan" dalam menata kehidupan masa depan dengan segala dinamika perubahannya yang harus dapat diantisipasi oleh generasi sekarang melalui penyiapan kemampuan membaca dan berfikir futuristic.

Dengan konsep Muttaqin dan Imama yang utuh dan sempurna, maka peradaban akan dihasilkannya, tidak hanya dalam bentuk idofact (ide gagasan), tapi dirasakan dalam wujud nyata dalam sosiofact (efek social/kemaslahatan ummat), bahkan diwujudkan dalam artifact (karya nyata) sebagai wujud peradaban yang betul-betul dengan profesionalitas dan menjadi peradaban dunia.

\section{Penutup}

Membangun generasi dengan peradaban yang luar biasa, salah satunya ditegaskan dalam al-Qur'an Surat alFurqon ayat 74, terutama dengan konsep Muttaqin dan Imam, yang dimulai dari memilih jodoh (pendidikan). Dalam hal ini Islam menggariskan dengan hadis Rasulullah SAW., yang kalau diterjemahkan di dalam pendidikan, pendidikan yang dipilih adalah yang mempunyai kriteria (1) لمالها (fasilitas lengkap), (2) لجمالها (visi misinya menarik), (3) لنسابها (jelas rujukannya al-Qur'an dan sunnah, dst.), (4) لدينها (landasan aqidahnya sesuai), dan (5) Selanjutnya, pendidikan tersebut diarahkan dalam rangka mencetak (رية قرة
اعين), dalam hal ini, adalah pendidikan pra, dasar dan menengah. Untuk selanjutnya diarahan dalam mencapai derajat (متقين), dan ini diraih sempurna lewat pendidikan sarjana (S-1/Sarjana), bahkan derjat (متقين) disempurnakan lagi lewat pendidikan pascasarjana strata dua (S-2/Magister) dan puncaknya adalah (امام) diraih dengan pendidikan di strata tiga (S-3/Doktor). Dan derajat tertinggi (امام) disempurnakan dengan Gelar Profesor di bidang/profesi apapun. Konsep Muttaqin dalam prespektif al-Qur'an Surat al-Furqon ayat 74 adalah konsep utuhnya, jadi angka satu, baru sempurna satu, perlu disempunakan lagi dengan strata magister, lalu lengkap sempurna dengan doktor, untuk memberi nilai tambah dan guna peran yang lebih dan luar biasa. Sebagai puncaknya, konsep mujtahid (professor) yang melampaui strata itu, sehingga menghasilkan betulbetul kreasi baru (discovery) yang selalu up to date "sholihun likulli zamaan wa makan" dalam menata kehidupan masa depan dengan segala dinamika perubahannya yang harus dapat diantisipasi oleh generasi sekarang melalui penyiapan kemampuan membaca dan berfikir futuristic. Jadi, dengan konsep Muttaqin dan Imama yang utuh dan sempurna, maka peradaban akan dihasilkannya, tidak hanya dalam bentuk idofact (ide gagasan), tapi dirasakan dalam wujud nyata dalam sosiofact (efek social/kemaslahatan ummat), bahkan diwujudkan dalam artifact (karya nyata) sebagai wujud peradaban yang betul-betul dengan profesionalitas dan menjadi peradaban dunia.

\section{Daftar Pustaka}

Abdul Mujib \& Juyuf Mudzakir. 2006. Ilmu Pendidikan Islam, Jakarta: Kencana.

Tharaba, M. Fahim. 2008. Kuliah Kapita Selekta Pendidikan Islam, Pendidikan Agama Islam. Malang: Fakultas Tarbiyah UIN Maulana Malik Ibrahim Malang.

Tharaba, M. Fahim. 2016. Dasar-dasar Pendidikan Islam. Malang: Dreamliterabuana.

Tharaba, M. Fahim. 2016. Kepemimpinan Pendidikan Islam (Islamic 
Educational Leadership), Malang: Dreamliterabuana.

Tharaba, M. Fahim. 2016. Kuliah Dasardasar Pendidikan Islam, Manajemen Pendidikan Islam, Malang: FITK UIN Maulana Malik Ibrahim Malang.

M. Hajar Dewantoro. 1997. Urgensi Inovasi Pendidikan Dalam Pemberdayaan Umat. dalam : Muslih Usa dan Aden Wijdan SZ [Penyunting], Pendidikan Islam dalam Peradaban Industrialisasi. Yogyakarta: Aditiya Media.

Winardi. 2005. Manajemen Perubahan, Jakarta: Kencana. 